
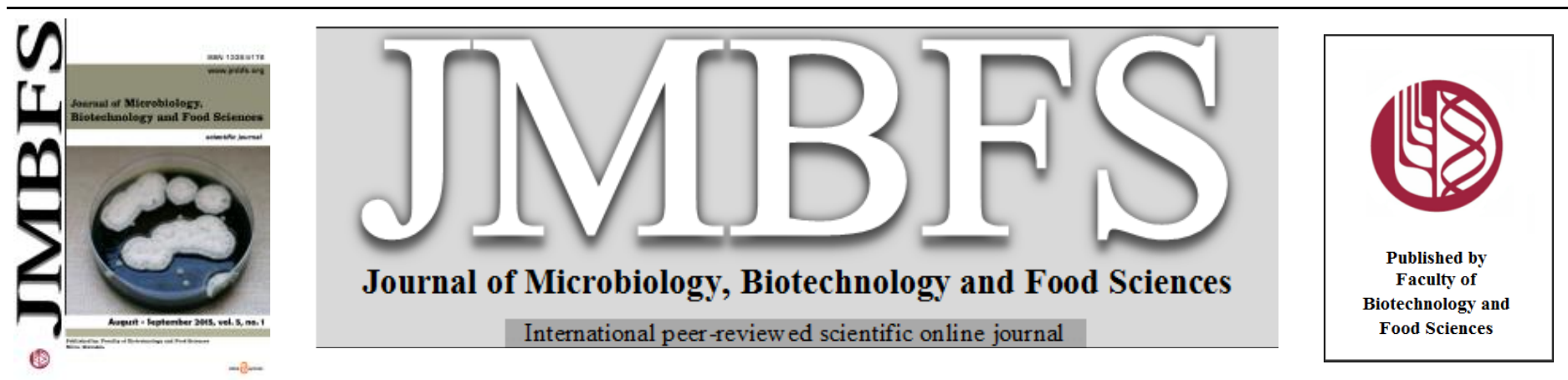

\title{
EFFECT OF MAGNESIUM D - GLUCONATE FORTIFICATION ON HEAT STABILITY OF GOAT'S MILK AND PHYSICOCHEMICAL PROPERTIES, SENSORY CHARACTERISTIC AND TEXTURE PROFILE OF YOGHURTS DURING COLD STORAGE
}

\section{Agata Znamirowska*, Katarzyna Szajnar, Matgorzata Pawlos, Dorota Kalicka}

Address(es):

University of Rzeszow, Faculty of Biology and Agriculture, Department of Dairy Technology, Ćwiklinskiej 2D St., 35-601 Rzeszow, +48177854903.

*Corresponding author: aznam@univ.rzeszow.pl

doi: $10.15414 / j m b f s .2015 .5 .1 .68-72$

\section{ARTICLE INFO}

Received 23. 4. 2015

Revised 20. 5. 2015

Accepted 25. 5. 2015

Published 1. 8. 2015

Regular article

OPEN PACCESS $_{\text {A }}$

\begin{abstract}
Average consumption of magnesium in Poland does not satisfy people's daily demand for this element; therefore it is necessary to supplement it. In the conducted experiment there was established the possibility of using magnesium D-gluconate for enriching yoghurts and goat's milk. The highest dose of magnesium, which did not cause protein precipitation during pasteurization, was the addition of 20 $\mathrm{mg}$ of magnesium for $100 \mathrm{~g}$ of goat's milk. Fortification with magnesium decreases $\mathrm{pH}$ and increases the hardness of yoghurts. Yoghurts enriched with magnesium during the whole storage period were better preferred by consumers than control yoghurts (without magnesium). Fortification with magnesium increases the intensity of milky-creamy taste and decreases the intensity of "goat" taste in goat's milk yoghurts. The amount of the introduced magnesium does not significantly change the cohesiveness and adhesiveness of yoghurts within 21-day-storage period.
\end{abstract}

Keywords: Magnesium, fortification, yoghurt, goat's milk

\section{INTRODUCTION}

Appropriate balance between particular elements in diet is necessary to correct functioning of a human body and maintain its homeostasis. More and more often you can come across the problem of biological deficiency of such an important element as magnesium. Magnesium is better assimilated as an ingredient of food products than pharmaceutical products. Milk is considered an average source of magnesium. In case of consumption of food, which is reach in phytates or proteins there might occur an interaction and decrease of the assimilation of magnesium. It is believed, that calcium disrupts assimilation of magnesium. However, the majority of research did not prove the influence of calcium on the assimilation of magnesium under the condition, that the daily dose of $2000 \mathrm{mg}$ $\mathrm{Ca}$ is not exceeded, which may in fact decrease the absorption of magnesium (Bancerz et al., 2012; Ziarno 2004). Assimilation of magnesium is lower when the consumption of protein in the diet is lower than $30 \mathrm{~g}$ daily. Significant increase in consumption of proteins can also influence the decrease of the concentration of magnesium, connected with the increased kidney secretion (Ziarno, 2004). Research of bioavailability of magnesium in 10 organic and nonorganic magnesium salts was made by Coudray et al. (2005) and there was proved that magnesium D-gluconate has the highest bioavailability of magnesium

It is forecasted that the consumption of yoghurts will be higher and higher and the properties of yoghurt qualify this product as a good carrier for magnesium in order to decrease the deficiencies of this element in diet. Currently a phenomenon of hypomagnesaemia is more and more often observed, especially in highly industrialised countries, also in Poland (Kocot, 2014). Scientists claim, that average consumption of magnesium by Poles does not correspond with a daily demand for this element (Jarosz and Bulhak - Jachymczuk, 2008). In such situations it is recommended to use supplementation of diet in magnesium, which is provided to the body with food products (Kruk - Slomka, 2012).

Goat's milk is counted as easily digestible and well-assimilated food for a human body and it is often used as a substitute in a diet of people who may be allergic to cow's milk proteins (Danków - Kubisz, 2007; Hekmat and Reid, 2006; Pieczonka, 2008; Danków and Pikul, 2011; Pandya, Ghodke, 2007). Goat milk contains a little of magnesium, from $12 \mathrm{mg}$ to $16 \mathrm{mg} \mathrm{Mg} / 100 \mathrm{~g}$ (Park et al., 2007; Ceballos et al., 2009; Brendehaug and Abrahamsen, 1986). Good assimilation of the ingredients of goat's milk and optimum contents of protein make goat's products good carriers of magnesium. Moreover, thermic processing used in the production of fermented milk drinks cause significant changes in the composition of mineral compounds of milk, including magnesium. Precipitation of insoluble magnesium compounds may cause as much as $50 \%$ of loss of this element. These technological losses caused by pasteurisation may be balanced by means of enriching milk in magnesium compounds.

The aim of the paper was to determine the possibility of using magnesium Dgluconate to enrich goat's milk before pasteurisation and to establish the dose of the introduced magnesium on acidity and heat stability of proteins. Moreover, there was determined the influence of applied dose of magnesium on the physicochemical and organoleptic properties and texture of yoghurts during 21 day period of storage.

\section{MATERIAL AND METHODS}

\section{Materials}

The research material was cumulative goat's milk collected three times in the middle of lactation (June-September). For milk and yoghurts enrichment magnesium D - gluconate hydrate $\geq 98 \%\left(\mathrm{C}_{12} \mathrm{H}_{22} \mathrm{MgO}_{14} \mathrm{XH}_{2} \mathrm{O}\right.$, pure for analysis, Sigma - Aldrich, USA) was used.

\section{Milk analysis}

In raw milk there were determined physicochemical and microbiologica parameters (Tab 1) and then fat was spun and the content of dry matter was normalized. The general number of micro-organisms and the number of somatic cells were determined in IBC M/SCC (Bentley) semi-automatic counter, and the chemical composition was determined in Bentley B-150 milk composition analyser. The chemical composition of milk used for production of yoghurts is presented in table 2 . 
Table 1 Quality of raw goat's milk

\begin{tabular}{ll}
\hline \hline Properties & Average \pm standard deviation \\
\hline \hline General number of micro-organisms & $359000 \pm 51000$ \\
$(\mathrm{CFU} / \mathrm{ml})$ & $400000 \pm 30000$ \\
Number of somatic cells $(1 \mathrm{ml})$ & $6.570 \pm 0.022$ \\
$\mathrm{pH}$ & $6.400 \pm 0.045$ \\
General acidity $\left({ }^{\circ} \mathrm{SH}\right)$ & $-0.569 \pm-0.002$ \\
Freezing point $\left({ }^{\circ} \mathrm{C}\right)$ & $2.580 \pm 0.032$ \\
Protein $(\%)$ & $3.440 \pm 0.500$ \\
Fat $(\%)$ & $4.200 \pm 0.025$ \\
Lactose $(\%)$ & $10.920 \pm 0.600$ \\
Dry matter $(\%)$ & \\
\hline \hline
\end{tabular}

Table 2 Chemical composition of normalized milk for production of yoghurts

\begin{tabular}{ll}
\hline \hline Properties & Average \pm standard deviation \\
\hline \hline Protein $(\%)$ & $3.88 \pm 0.06$ \\
Fat $(\%)$ & $2.06 \pm 0.26$ \\
Lactose $(\%)$ & $6.45 \pm 0.04$ \\
Dry matter $(\%)$ & $13.90 \pm 0.31$ \\
\hline \hline
\end{tabular}

Heat stability of milk enriched in magnesium D - gluconate

The experiment was conducted in two stages. The scope of tests of the first stage included determining the quantity of addition of magnesium D - gluconate hydrate $\geq 98 \%\left(\mathrm{C}_{12} \mathrm{H}_{22} \mathrm{MgO}_{14} \mathrm{xH}_{2} \mathrm{O}\right.$, pure for analysis, Sigma - Aldrich, USA) not causing thermal denaturation of proteins of milk during its pasteurization in temperature of $72^{\circ} \mathrm{C}$ for 15 seconds. The doses of magnesium presented in tables were calculated based on molecular weight of magnesium gluconate. The experiment started with the dose of $1 \mathrm{mg}$ of magnesium for $100 \mathrm{~g}$ of milk and continued until denaturation occurred during pasteurization. There was also made a test sample without addition of magnesium. After cooling milk samples $\mathrm{pH}$ was determined.

\section{Preparation of yoghurts}

The scope of the second stage of tests included production of yoghurt with the thermostatic method of various levels of enrichment with magnesium $(0 \mathrm{mg}, 5$ $\mathrm{mg}, 10 \mathrm{mg}, 15 \mathrm{mg}$ and $20 \mathrm{mg}$ ) with the use of the vaccine FD-DVS YC-X16 (Chr. Hansen). Fermentation was conducted for 4.5 hours in disposable containers with lids $(100 \mathrm{ml})$ in temperature of $43^{\circ} \mathrm{C}$.

\section{Yoghurts analysis}

The assessment of the influence of addition of magnesium gluconate on acidity, texture and sensory characteristics (1-9 points) was conducted at four fixed dates, i.e. after 1 day, 7 days, 14 days and 21 days of storage. Preferences were determined by ranking method (9 - the most preferred yoghurt, 1 - the leas preferred yoghurt). Determining potential acidity was performed by titration of $0.25 \mathrm{~N}$ samples with standard solution of sodium hydroxide in presence of phenolphthalein as an indicator. Determining active acidity $(\mathrm{pH})$ was performed with the electrometric method by measurement of activity of hydrogen ions with the use of $\mathrm{pH} /$ conductivity meter $\mathrm{CPC}-505$ (Elmetron) equipped with the combination electrode OSH $12-00$. The texture was determined with the analyser Brookfield CT3 equipped with Brookfield Texture Pro CT software. For determination there was selected the TPA test with the following settings: sample - cylinder $66.00 \mathrm{~mm}$ x $33.86 \mathrm{~mm}$, force $0.1 \mathrm{~N}$, head speed $1 \mathrm{~mm} / \mathrm{s}$, table TA-BTKIT, probe TA3/100.

\section{Statistical analysis}

The obtained results were worked out statistically in the software Statistica v.10 with the use of one-way analysis of variance, and significance of differences between the averages was estimated with Tukey's test.

\section{RESULTS AND DISCUSSION}

\section{Effect of pasteurization on enriched goat's milk}

Magnesium D-gluconate belongs to the water-soluble compounds that cause the appearance of considerable amounts of ionic forms of magnesium. $70-75 \%$ of magnesium in the fresh milk is in the form of soluble salts, the remaining part of magnesium occurs as a colloidal compounds (phosphate and citrate). Only $15 \%$ of the magnesium in fresh milk is in the free ionic form. Increasing the amount of magnesium ions reduces the stability of milk proteins which can cause the thermal coagulation (Ścibisz et al., 2012; Zaręba et al., 2012).

The conducted tests have proven that the highest dose of magnesium which does not caused the precipitation of proteins after pasteurization was $20 \mathrm{mg}$ of magnesium for $100 \mathrm{~g}$ of goat milk. The dose of fortification with magnesium causing precipitation of proteins after pasteurization in $75^{\circ} \mathrm{C}$ was $21 \mathrm{mg}$ of magnesium for $100 \mathrm{~g}$ of milk. It was also observed that putting of higher and higher doses of magnesium D-gluconate caused a reduction of $\mathrm{pH}$ of milk (Fig 1). Enriching milk with the dose of $20 \mathrm{mg}$ of magnesium (for $100 \mathrm{mg}$ of milk) caused a reduction of active acidity from 6.530 (milk without addition of magnesium D-gluconate) to 6.250 .

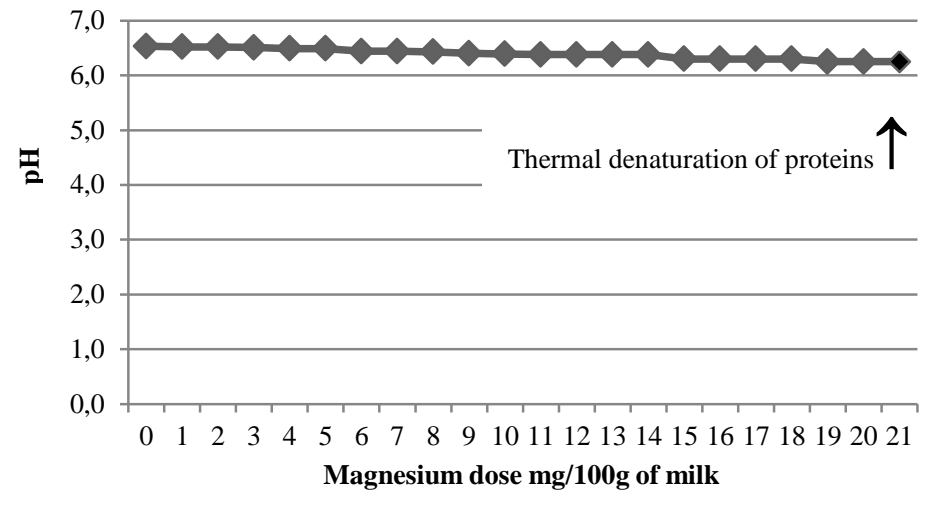

Figure 1 Influence of applied dose of magnesium in the form of D-gluconate on $\mathrm{pH}$ of milk after pasteurization

\section{Effect of fortification on acidity of yoghurts}

Yoghurts enriched in 5,10,15, $20 \mathrm{mg}$ of magnesium (for $100 \mathrm{~g}$ of processed milk) were characterized during the 21 days of storage by higher values of $\mathrm{pH}$ in comparison to test yoghurts, without addition of magnesium D-gluconate. On the first day of storage the highest $\mathrm{pH}=4.541$ were determined in yoghurts enriched with the dose of $20 \mathrm{mg}$ of magnesium (for $100 \mathrm{~g}$ of milk for production) and the lowest values of $\mathrm{pH}$ (4.335) were determined in test yoghurts. There were found significant differences in active acidity between samples enriched in $20 \mathrm{mg}$ of magnesium and test samples without addition of magnesium D-gluconate Moreover, in all groups of yoghurts during successive weeks of cold storage, it was observed a reduction of $\mathrm{pH}$ and there were found statistically significant differences (Tab 3). According to Mituniewicz-Małek $\boldsymbol{e t}$ al. (2013) the active acidity of goat's yoghurts (produced with the use of $\mathrm{Lb}$. casei 01 inoculant) on first day of storage was 5.330 and it decreased to 4.410 after 21 days of cold storage.

Table 3 The influence of dose of enrichment with magnesium on active acidity of goat's milk yoghurts during storage

\begin{tabular}{|c|c|c|c|c|c|}
\hline \multirow{2}{*}{$\begin{array}{l}\text { Characteristic - fixed date of } \\
\text { determination }\end{array}$} & \multicolumn{5}{|c|}{ Dose of enrichment with magnesium (mg of magnesium for $100 \mathrm{~g}$ of milk) } \\
\hline & 0 & 5 & 10 & 15 & 20 \\
\hline$\overline{\mathrm{pH}}-1$ day & $4.335 \pm 0.017^{\mathrm{aA}}$ & $4.396 \pm 0.027^{\mathrm{aA}}$ & $4.455 \pm 0.065^{\mathrm{aA}}$ & $\overline{4.451 \pm 0.066^{\mathrm{aA}}}$ & $4.541 \pm 0.190^{\mathrm{bA}}$ \\
\hline pH - 7 days & $4.198 \pm 0.093^{\mathrm{aAB}}$ & $4.242 \pm 0.055^{\mathrm{aB}}$ & $4.242 \pm 0.047^{\mathrm{aB}}$ & $4.258 \pm 0.048^{\mathrm{aB}}$ & $4.270 \pm 0.048^{\mathrm{aB}}$ \\
\hline $\mathrm{pH}-14$ days & $4.271 \pm 0.003^{\mathrm{aAB}}$ & $4.231 \pm 0.039^{\mathrm{aB}}$ & $4.230 \pm 0.066^{\mathrm{aB}}$ & $4.212 \pm 0.051^{\mathrm{aB}}$ & $4.235 \pm 0.045^{\mathrm{aB}}$ \\
\hline $\mathrm{pH}-21$ days & $4.151 \pm 0.068^{\mathrm{aB}}$ & $4.189 \pm 0.043^{\mathrm{aB}}$ & $4.186 \pm 0.051^{\mathrm{aB}}$ & $4.187 \pm 0.032^{\mathrm{aB}}$ & $4.200 \pm 0.042^{\mathrm{aB}}$ \\
\hline
\end{tabular}

Legend: ${ }^{\mathrm{a}-\mathrm{c}}-$ statistically significant differences $(\mathrm{p}<0.05)$ analysed in row

A-C - statistically significant differences $(\mathrm{p}<0.05)$ analysed in column 


\section{Effect of fortification on sensory and textural properties of yoghurts}

Non - fortified goat's milk yoghurts were the least preferred by the sensory panel during whole period of cold storage. The sensory panel preferred yoghurts enriched in magnesium on 7th, 14th and 21st day of sensory assessment and yoghurts enriched with a dose of $15 \mathrm{mg}$ of magnesium (for $100 \mathrm{~g}$ of milk for production) were chosen as the best. Yoghurts enriched in $5 \mathrm{mg}$ of magnesium were preferably chosen on 1st day of storage. Mituniewicz - Malek et al. (2013) found that goat's milk fermented beverages containing a new generation of probiotic single strains Lactobacillus sp. (Lb. paracasei AD 400, Lb. casei 01 oraz $L b$. acidophilus 3 ) also showed very good sensory characteristics during cold storage.

\begin{tabular}{|c|c|c|c|c|c|}
\hline \multirow{2}{*}{$\begin{array}{l}\text { Characteristic - fixed date of } \\
\text { determination }\end{array}$} & \multicolumn{5}{|c|}{ Dose of enrichment with magnesium ( $\mathrm{mg}$ of magnesium for $100 \mathrm{~g}$ of milk) } \\
\hline & 0 & 5 & 10 & 15 & 20 \\
\hline Preference - 1 day & $4.556 \pm 2.068^{\mathrm{aA}}$ & $2.000 \pm 1.118^{\mathrm{aA}}$ & $4.555 \pm 2.550^{\mathrm{aA}}$ & $3.889 \pm 2.205^{\mathrm{aA}}$ & $3.444 \pm 1.810^{\mathrm{aA}}$ \\
\hline Preference -7 days & $4.556 \pm 2.128^{\mathrm{aA}}$ & $3.333 \pm 1.732^{\mathrm{abA}}$ & $3.667 \pm 2.000^{\mathrm{abA}}$ & $3.000 \pm 1.500^{\mathrm{bA}}$ & $3.778 \pm 1.986^{\mathrm{abA}}$ \\
\hline Preference - 14 days & $4.375 \pm 2.560^{\mathrm{aA}}$ & $4.375 \pm 1.847^{\mathrm{abA}}$ & $3.875 \pm 2.357^{\mathrm{abA}}$ & $2.375 \pm 1.188^{\mathrm{bA}}$ & $3.000 \pm 2.000^{\mathrm{abA}}$ \\
\hline Preference -21 days & $4.111 \pm 2.522^{\mathrm{aA}}$ & $3.778 \pm 1.922^{\mathrm{abA}}$ & $3.111 \pm 1.764^{\mathrm{abA}}$ & $2.222 \pm 1.093^{\mathrm{bA}}$ & $3.889 \pm 1.900^{\mathrm{abA}}$ \\
\hline
\end{tabular}

Legend: ${ }^{\mathrm{a}-\mathrm{c}}-$ statistically significant differences $(\mathrm{p}<0.05)$ analysed in row

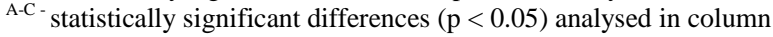

Goat's yoghurts of all experimental groups were characterized by a white colour assessed by the team in the range of 8.556 points to 9.000 points (Tab 5).
Moreover, there was no significant differences in colour of yoghurts depending upon fortification with magnesium and storage time.

Table 5 The influence of dose of enrichment with magnesium on colour of goat's milk yoghurts during storage (1-9 points)

\begin{tabular}{|c|c|c|c|c|c|}
\hline \multirow{2}{*}{$\begin{array}{l}\text { Characteristic - fixed date of } \\
\text { determination }\end{array}$} & \multicolumn{5}{|c|}{ Dose of enrichment with magnesium (mg of magnesium for $100 \mathrm{~g}$ of milk) } \\
\hline & 0 & 5 & 10 & 15 & 20 \\
\hline Colour - 1 day & $8.556 \pm 0.726^{\mathrm{aA}}$ & $8.556 \pm 0.726^{\mathrm{aA}}$ & $8.556 \pm 0.726^{\mathrm{aA}}$ & $8.556 \pm 0.726^{\mathrm{aA}}$ & $8.556 \pm 0.726^{\mathrm{aA}}$ \\
\hline Colour -7 days & $8.556 \pm 0.882^{\mathrm{aA}}$ & $8.556 \pm 0.882^{\mathrm{aA}}$ & $8.556 \pm 0.882^{\mathrm{aA}}$ & $8.556 \pm 0.882^{\mathrm{aA}}$ & $8.556 \pm 0.882^{\mathrm{aA}}$ \\
\hline Colour - 14 days & $8.875 \pm 0.354^{\mathrm{aA}}$ & $8.875 \pm 0.354^{\mathrm{aA}}$ & $8.875 \pm 0.354^{\mathrm{aA}}$ & $8.875 \pm 0.354^{\mathrm{aA}}$ & $8.875 \pm 0.354^{\mathrm{aA}}$ \\
\hline Colour - 21days & $9.000 \pm 0.000^{\mathrm{aA}}$ & $9.000 \pm 0.000^{\mathrm{aA}}$ & $9.000 \pm 0.000^{\mathrm{aA}}$ & $9.000 \pm 0.000^{\mathrm{aA}}$ & $9.000 \pm 0.000^{\mathrm{aA}}$ \\
\hline
\end{tabular}

Legend: ${ }^{\mathrm{a}-\mathrm{c}}-$ statistically significant differences $(\mathrm{p}<0.05)$ analysed in row

$$
{ }^{A-C} \text { - statistically significant differences }(\mathrm{p}<0.05) \text { analysed in column }
$$

Goat's milk products are particularly exposed to occurrence of defects in texture lower consistence of curd produced by the thermostatic method, too liquid consistence and low viscosity of curd produced by a tank method (Szczepanik and Libudzisz, 2000). In the experiment there was observed positive effect of enrichment on the consistency, especially in yoghurts fortified with $20 \mathrm{mg}$ of magnesium (for $100 \mathrm{~g}$ of processed milk) in comparison to non-fortified yoghurts (Tab 6). According to Znamirowska et al. (2015) fortification of goat's yoghurt with magnesium chloride ( $20 \mathrm{mg}$ of magnesium for $100 \mathrm{~g}$ of milk for production) has a positive effect on consistency.

Table 6 The influence of dose of enrichment with magnesium on consistency of goat's milk yoghurts during storage (1-9 points)

\begin{tabular}{|c|c|c|c|c|c|}
\hline \multirow{2}{*}{$\begin{array}{l}\text { Characteristic - fixed date } \\
\text { of determination }\end{array}$} & \multicolumn{5}{|c|}{ Dose of enrichment with magnesium (mg of magnesium for $100 \mathrm{~g}$ of milk) } \\
\hline & 0 & 5 & 10 & 15 & 20 \\
\hline Consistency - 1 day & $7.111 \pm 1.616^{\mathrm{aA}}$ & $7.889 \pm 0.928^{\mathrm{aA}}$ & $7.000 \pm 1.936^{\mathrm{aA}}$ & $7.333 \pm 1.236^{\mathrm{aA}}$ & $7.089 \pm 0.928^{\mathrm{aA}}$ \\
\hline Consistency -7 days & $7.222 \pm 1.416^{\mathrm{aA}}$ & $7.667 \pm 0.866^{\mathrm{aA}}$ & $7.222 \pm 1.716^{\mathrm{aA}}$ & $7.778 \pm 1.092^{\mathrm{aA}}$ & $8.111 \pm 0.928^{\mathrm{aA}}$ \\
\hline Consistency -14 days & $7.625 \pm 1.302^{\mathrm{aA}}$ & $7.875 \pm 0.991^{\mathrm{aA}}$ & $7.000 \pm 2.619^{\mathrm{aA}}$ & $7.725 \pm 1.588^{\mathrm{aA}}$ & $8.000 \pm 1.069^{\mathrm{aA}}$ \\
\hline Consistency -21 days & $7.889 \pm 1.167^{\mathrm{aA}}$ & $8.222 \pm 1.302^{\mathrm{aA}}$ & $7.889 \pm 1.167^{\mathrm{aA}}$ & $8.222 \pm 1.302^{\mathrm{aA}}$ & $8.222 \pm 1.302^{\mathrm{aA}}$ \\
\hline
\end{tabular}

Legend: ${ }^{a-c}-$ statistically significant differences $(p<0.05)$ analysed in row A-C - statistically significant differences $(\mathrm{p}<0.05)$ analysed in column

Table 7 presents the results of the assessment of intensity of milky - creamy taste in all groups of yoghurts. In control yoghurts, non-fortified with magnesium Dgluconate, there was found less intense milky-creamy taste. The sensory panel found that fortification with magnesium increases perceptibility of milky-creamy taste in goat's yoghurts.

Table 7 The influence of doses of enrichment with magnesium on perceptibility of milky-creamy taste of goat's milk yoghurts during storage (1-9 points)

\begin{tabular}{|c|c|c|c|c|c|}
\hline \multirow{2}{*}{$\begin{array}{l}\text { Characteristic - fixed date of } \\
\text { determination }\end{array}$} & \multicolumn{5}{|c|}{ Dose of enrichment with magnesium ( $\mathrm{mg}$ of magnesium for $100 \mathrm{~g}$ of milk) } \\
\hline & 0 & 5 & 10 & 15 & 20 \\
\hline Milky-creamy taste - 1 day & $4.556 \pm 1.046^{\mathrm{aA}}$ & 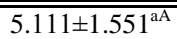 & $5.333 \pm 1.606^{\mathrm{aA}}$ & $4.889 \pm 1.804^{\mathrm{aA}}$ & $4.667 \pm 1.240^{\mathrm{aA}}$ \\
\hline Milky-creamy taste -7 days & $4.778 \pm 1.949^{\mathrm{aA}}$ & $5.556 \pm 1.046^{\mathrm{aA}}$ & $5.222 \pm 1.949^{\mathrm{aA}}$ & $5.667 \pm 1.041^{\mathrm{aA}}$ & $5.778 \pm 1.032^{\mathrm{aA}}$ \\
\hline Milky-creamy taste -14 days & $3.750 \pm 1.412^{\mathrm{aA}}$ & $4.125 \pm 1.357^{\mathrm{aA}}$ & $4.375 \pm 1.021^{\mathrm{aA}}$ & $4.500 \pm 1.295^{\mathrm{aA}}$ & $4.375 \pm 1.378^{\mathrm{aA}}$ \\
\hline Milky-creamy taste -21 days & $4.000 \pm 1.041^{\mathrm{aA}}$ & $4.889 \pm 1.180^{\mathrm{aA}}$ & $5.111 \pm 1.759^{\mathrm{aA}}$ & $4.778 \pm 1.949^{\mathrm{aA}}$ & $4.892 \pm 1.892^{\mathrm{aA}}$ \\
\hline
\end{tabular}

Legend: ${ }^{a-c}-$ statistically significant differences $(p<0.05)$ analysed in row

A-C - statistically significant differences $(p<0.05)$ analysed in column

The carried-out experiment shows that the fortification with magnesium decreases sourness of the yoghurt's taste in comparison to non-fortified ones (Tab 8). Moreover, in all groups of yoghurts there were found an increase of perceptibility of sour taste during the 21 days of cold storage. Confirmation of this trend is an increase of active acidity during successive weeks of cold storage. 
Table 8 The influence of dose of enrichment with magnesium on perceptibility of sour taste of goat's milk yoghurts (1-9 points) during storage

\begin{tabular}{|c|c|c|c|c|c|}
\hline \multirow{2}{*}{$\begin{array}{l}\text { Characteristic - fixed date of } \\
\text { determination }\end{array}$} & \multicolumn{5}{|c|}{ Dose of enrichment with magnesium (mg of magnesium for $100 \mathrm{~g}$ of milk) } \\
\hline & 0 & 5 & 10 & 15 & 20 \\
\hline Sour taste -1 day & $\overline{5.167 \pm 1.871^{\mathrm{aA}}}$ & $4.667 \pm 1.323^{\mathrm{aA}}$ & $\overline{4.444 \pm 1.944^{\mathrm{aA}}}$ & $\overline{4.111 \pm 1.261^{\mathrm{aA}}}$ & $4.222 \pm 1.438^{\mathrm{aA}}$ \\
\hline Sour taste -7 days & $5.000 \pm 1.936^{\mathrm{aA}}$ & $4.667 \pm 1.803^{\mathrm{aA}}$ & $4.333 \pm 1.121^{\mathrm{aA}}$ & $4.444 \pm 1.236^{\mathrm{aA}}$ & $4.444 \pm 1.068^{\mathrm{aA}}$ \\
\hline Sour taste - 14 days & $5.250 \pm 1.435^{\mathrm{aA}}$ & $4.375 \pm 1.768^{\mathrm{aA}}$ & $4.125 \pm 1.167^{\mathrm{aA}}$ & $4.875 \pm 1.357^{\mathrm{aA}}$ & $4.375 \pm 1.134^{\mathrm{aA}}$ \\
\hline Sour taste -21 days & $6.222 \pm 1.986^{\mathrm{aA}}$ & $5.111 \pm 1.205^{\mathrm{aA}}$ & $5.000 \pm 1.646^{\mathrm{aA}}$ & $5.000 \pm 1.398^{\mathrm{aA}}$ & $5.222 \pm 1.224^{\mathrm{aA}}$ \\
\hline
\end{tabular}

Legend: ${ }^{\mathrm{a}-\mathrm{c}}-$ statistically significant differences $(\mathrm{p}<0.05)$ analysed in row A-C - statistically significant differences $(\mathrm{p}<0.05)$ analysed in column

Unfavorable "goat" taste is caused by lipolytic processes, because in goat milk lipoprotein lipase is arranged on the surface of the fat globules in $46 \%$, in milk's serum in $46 \%$, while on the surface of casein micelles in $8 \%$, which decides on a "goat" smell of milk (Danków - Kubisz, 2007). Furthermore, in goat's milk fat there is shown a high proportion of short- and medium-chain fatty acids (15\%), which are responsible for the specific "goat" taste and smell of milk (Danków and Pikul, 2011). With extension of storage time the intensity of "goat" taste increased in yoghurts enriched with $5 \mathrm{mg}, 10 \mathrm{mg}, 15 \mathrm{mg}$ of magnesium and in a non-fortified ones (Tab 9). The most intensive "goat" taste was determined in yoghurts not enriched in magnesium on 21st day of storage. The least intense "goat" taste was determined in yoghurts fortified with $20 \mathrm{mg}$ of $\mathrm{Mg}$ on 14th and 21 st day of storage. In these yoghurts there was not observed goat smell $(1,000$ pts.), abnormal taste (1,000 pts.) and smell (1,000 pts.). According to
Znamirowska et al. (2015) the use of enrichments with magnesium and production of goat yoghurt which, as a result of fortification, does not take sour and goat taste together with extension of storage time and has a nice smell, is a good prospect for promotion of goat's milk functional beverages. The most favorable solution for the industrial technology is production of yoghurt enriched with a dose of at least $10 \mathrm{mg}$ of magnesium for $100 \mathrm{~g}$ of milk. It is highly probable that this kind of yoghurt will be most eagerly purchased by consumers. The most intensive sour smell was found in control yoghurts on 7th, 14th and 21 st day of cold storage (Tab 10). In yoghurts fortified with magnesium there was found less intense sour smell, however the results of assessmet do not showed signifcant differences between the dose of enrichment and intensivity of sour smell. Also there was not observed a significant effect of storage time on the intensity of sour smell of yoghurt.

Table 9 The influence of dose of enrichment with magnesium on perceptibility of goat taste of goat's milk yoghurts during storage (1-9 points)

\begin{tabular}{|c|c|c|c|c|c|}
\hline \multirow{2}{*}{$\begin{array}{l}\text { Characteristic - fixed date of } \\
\text { determination }\end{array}$} & \multicolumn{5}{|c|}{ Dose of enrichment with magnesium (mg of magnesium for $100 \mathrm{~g}$ of milk) } \\
\hline & 0 & 5 & 10 & 15 & 20 \\
\hline "Goat" taste - 1 day & $1.200 \pm 1.200^{\mathrm{aA}}$ & $1.200 \pm 0.447^{\mathrm{aA}}$ & $1.200 \pm 0.447^{\mathrm{aA}}$ & $1.200 \pm 0.447^{\mathrm{aA}}$ & $1.800 \pm 0.836^{\mathrm{aA}}$ \\
\hline "Goat" taste -7 days & $1.500 \pm 0.836^{\mathrm{aAB}}$ & $1.500 \pm 0.836^{\mathrm{aAB}}$ & $1.333 \pm 0.516^{\mathrm{aAB}}$ & $1.400 \pm 0.547^{\mathrm{aAB}}$ & $1.800 \pm 0.836^{\mathrm{aA}}$ \\
\hline "Goat" taste -14 days & $1.750 \pm 0.500^{\mathrm{aAB}}$ & $1.750 \pm 0.447^{\mathrm{aAB}}$ & $1.500 \pm 0.516^{\mathrm{aAB}}$ & $1.500 \pm 0.500^{\mathrm{aAB}}$ & $1.400 \pm 0.447^{\mathrm{aAB}}$ \\
\hline "Goat" taste -21 days & $2.333 \pm 0.266^{\mathrm{aB}}$ & $2.333 \pm 0.805^{\mathrm{aB}}$ & $2.167 \pm 0.858^{\mathrm{aB}}$ & $2.000 \pm 0.449^{\mathrm{aB}}$ & $1.200 \pm 0.447^{\mathrm{aB}}$ \\
\hline
\end{tabular}

Legend: ${ }^{\mathrm{a}-\mathrm{c}}-$ statistically significant differences $(\mathrm{p}<0.05)$ analysed in row

A-C - statistically significant differences $(\mathrm{p}<0.05)$ analysed in column

Table 10 The influence of dose of enrichment with magnesium on perceptibility of sour smell of goat's milk yoghurts during storage (1-9 points)

\begin{tabular}{|c|c|c|c|c|c|}
\hline \multirow{2}{*}{$\begin{array}{l}\text { Characteristic - fixed date of } \\
\text { determination }\end{array}$} & \multicolumn{5}{|c|}{ Dose of enrichment with magnesium (mg of magnesium for $100 \mathrm{~g}$ of milk) } \\
\hline & 0 & 5 & 10 & 15 & 20 \\
\hline Sour smell - 1 day & $3.222 \pm 1.922^{\mathrm{aA}}$ & $3.444 \pm 1.506^{\mathrm{aA}}$ & $3.000 \pm 1.500^{\mathrm{aA}}$ & $2.444 \pm 1.590^{\mathrm{aA}}$ & $2.444 \pm 1.333^{\mathrm{aA}}$ \\
\hline Sour smell - 7 days & $4.000 \pm 1.550^{\mathrm{aA}}$ & $3.449 \pm 1.616^{\mathrm{abA}}$ & $2.189 \pm 1.364^{\mathrm{bA}}$ & $2.667 \pm 1.871^{\mathrm{abA}}$ & $2.333 \pm 1.936^{\mathrm{abA}}$ \\
\hline Sour smell - 14 days & $4.050 \pm 1.435^{\mathrm{aA}}$ & $3.125 \pm 1.808^{\mathrm{aA}}$ & $2.125 \pm 0.835^{\mathrm{aA}}$ & $2.500 \pm 1.604^{\mathrm{aA}}$ & $2.750 \pm 1.832^{\mathrm{aA}}$ \\
\hline Sour smell - 21days & $4.000 \pm 1.500^{\mathrm{aA}}$ & $3.444 \pm 1.068^{\mathrm{aA}}$ & $3.111 \pm 1.261^{\mathrm{aA}}$ & $3.444 \pm 1.509^{\mathrm{aA}}$ & $3.444 \pm 1.667^{\mathrm{aA}}$ \\
\hline
\end{tabular}

Legend: ${ }^{a-c}-$ statistically significant differences $(\mathrm{p}<0.05)$ analysed in row

$$
\text { A-C - statistically significant differences }(\mathrm{p}<0.05) \text { analysed in column }
$$

Goat's milk yoghurts are particularly exposed to occurrence of defects in texture - the most important characteristics of quality of milk fermented beverages (Lankes et al., 1998; Szczepanik and Libudzisz, 2000; Wszołek, 1997) Defects in texture, besides defects in taste and smell, are the cause of lower consumer acceptance of this group of dairy products. The acid curd from goat's milk is characterized by lower conciseness and viscosity than the curd from cow's milk (Szczepanik and Libudzisz, 2000; Wszolek, 1997). The conducted tests proved that the highest hardness of curd was observed in yoghurts enriched in $15 \mathrm{mg}$ and $20 \mathrm{mg}$ of magnesium during whole period of storage (Tab 11). The lowest hardness was observed in non-fortified yogurts ( $0 \mathrm{mg}$ of magnesium) for the whole period of the experiment. Enrichment with magnesium increases the hardness of yoghurts. There were found significant differences in hardness of curd in yoghurts enriched with $0 \mathrm{mg}, 5 \mathrm{mg}$ of magnesium and hardness of yoghurts fortified in $15 \mathrm{mg}$ and $20 \mathrm{mg}$ of magnesium $(\mathrm{p} \leq 0.05)$. According to Mituniewicz - Malek et al. (2013) hardness of drink produced with the use of Lb. acidophilus 3 inoculant on 21 st day of cold storage was $0.466 \mathrm{~N}$.

The effect of the applied dose of magnesium on the cohesiveness of yoghurt from goat's milk is shown in table 12. Enrichment with magnesium does not significantly affect on the cohesiveness of yoghurt and the obtained values were in the range from 0.537 to 0.723 . There was not observed a significant difference in adhesiveness of yoghurts during whole period of storage.

Table 11 The influence of dose of enrichment with magnesium on hardness of curds in goat's milk yoghurts during storage (N)

\begin{tabular}{|c|c|c|c|c|c|}
\hline \multirow{2}{*}{$\begin{array}{l}\text { Characteristic - fixed date of } \\
\text { determination }\end{array}$} & \multicolumn{5}{|c|}{ Dose of enrichment with magnesium ( $\mathrm{mg}$ of magnesium for $100 \mathrm{~g}$ of milk) } \\
\hline & 0 & 5 & 10 & 15 & 20 \\
\hline Hardness - 1 day & $0.890 \pm 0.112^{\mathrm{aA}}$ & $0.766 \pm 0.065^{\mathrm{aA}}$ & $0.895 \pm 0.073^{\mathrm{bA}}$ & $1.222 \pm 0.361^{\mathrm{cA}}$ & $1.138 \pm 0.345^{\mathrm{cA}}$ \\
\hline Hardness -7 days & $0.860 \pm 0.042^{\mathrm{aA}}$ & $0.750 \pm 0.110^{\mathrm{aA}}$ & $0.873 \pm 0.094^{\mathrm{aA}}$ & $1.190 \pm 0.362^{\mathrm{bA}}$ & $1.308 \pm 0.287^{\mathrm{cA}}$ \\
\hline Hardness - 14 days & $0.673 \pm 0.085^{\mathrm{aA}}$ & $0.760 \pm 0.090^{\mathrm{aA}}$ & $0.895 \pm 0.110^{\mathrm{aA}}$ & $1.180 \pm 0.420^{\mathrm{bA}}$ & $1.281 \pm 0.227^{\mathrm{cA}}$ \\
\hline Hardness -21 days & $0.691 \pm 0.091^{\mathrm{aA}}$ & $0.810 \pm 0.060^{\mathrm{aA}}$ & $0.880 \pm 0.112^{\mathrm{bA}}$ & $1.152 \pm 0.308^{\mathrm{bA}}$ & $1.506 \pm 0.103^{\mathrm{cB}}$ \\
\hline
\end{tabular}

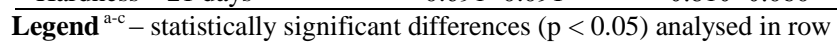

A-C - statistically significant differences $(\mathrm{p}<0.05)$ analysed in column 
Table 12 The influence of dose of enrichment with magnesium on cohesiveness of curds in goat's milk yoghurts during storage (mm)

\begin{tabular}{|c|c|c|c|c|c|}
\hline \multirow{2}{*}{$\begin{array}{l}\text { Characteristic - fixed date of } \\
\text { determination }\end{array}$} & \multicolumn{5}{|c|}{ Dose of enrichment with magnesium ( $\mathrm{mg}$ of magnesium for $100 \mathrm{~g}$ of milk) } \\
\hline & 0 & 5 & 10 & 15 & 20 \\
\hline Cohesiveness - 1 day & $0.605 \pm 0.089^{\mathrm{aA}}$ & $0.602 \pm 0.178^{\mathrm{aA}}$ & $0.643 \pm 0.040^{\mathrm{aA}}$ & $0.545 \pm 0.140^{\mathrm{aA}}$ & $0.625 \pm 0.098^{\mathrm{aA}}$ \\
\hline Cohesiveness -7 days & $0.640 \pm 0.065^{\mathrm{aA}}$ & $0.598 \pm 0.183^{\mathrm{aA}}$ & $0.655 \pm 0.028^{\mathrm{aA}}$ & $0.494 \pm 0.248^{\mathrm{aA}}$ & $0.587 \pm 0.100^{\mathrm{aA}}$ \\
\hline Cohesiveness -14 days & $0.642 \pm 0.107^{\mathrm{aA}}$ & $0.566 \pm 0.177^{\mathrm{aA}}$ & $0.723 \pm 0.058^{\mathrm{aA}}$ & $0.537 \pm 0.319^{\mathrm{aA}}$ & $0.625 \pm 0.163^{\mathrm{aA}}$ \\
\hline Cohesiveness -21 days & $0.672 \pm 0.166^{\mathrm{aA}}$ & $0.595 \pm 0.175^{\mathrm{aA}}$ & $0.713 \pm 0.045^{\mathrm{aA}}$ & $0.645 \pm 0.218^{\mathrm{aA}}$ & $0.645 \pm 0.194^{\mathrm{aA}}$ \\
\hline
\end{tabular}

Legend: ${ }^{\mathrm{a}-\mathrm{c}}-$ statistically significant differences $(\mathrm{p}<0.05)$ analysed in row

A-C - statistically significant differences $(\mathrm{p}<0.05)$ analysed in column

Table 13 The influence of dose of enrichment with magnesium on adhesiveness of curds in goat's milk yoghurts during storage (N)

\begin{tabular}{|c|c|c|c|c|c|}
\hline \multirow{2}{*}{$\begin{array}{l}\text { Characteristic - fixed date of } \\
\text { determination }\end{array}$} & \multicolumn{5}{|c|}{ Dose of enrichment with magnesium (mg of magnesium for $100 \mathrm{~g}$ of milk) } \\
\hline & 0 & 5 & 10 & 15 & 20 \\
\hline "Adhesiveness -1 day & $\overline{0.072 \pm 0.010^{\mathrm{aA}}}$ & $\overline{0.133 \pm 0.041^{\mathrm{abA}}}$ & $\overline{0.096 \pm 0.005^{\mathrm{aA}}}$ & $0.599 \pm 0.450^{\mathrm{bA}}$ & $\overline{0.318 \pm 0.551^{\mathrm{abA}}}$ \\
\hline Adhesiveness -7 days & $0.097 \pm 0.006^{\mathrm{aB}}$ & $0.023 \pm 0.005^{\mathrm{aA}}$ & $0.123 \pm 0.073^{\mathrm{aA}}$ & $0.034 \pm 0.038^{\mathrm{aA}}$ & $0.028 \pm 0.005^{\mathrm{aA}}$ \\
\hline Adhesiveness -14 days & $0.050 \pm 0.010^{\mathrm{aA}}$ & $0.020 \pm 0.000^{\mathrm{aA}}$ & $0.020 \pm 0.050^{\mathrm{aA}}$ & $0.062 \pm 0.077^{\mathrm{aA}}$ & $0.032 \pm 0.004^{\mathrm{aA}}$ \\
\hline Adhesiveness - 21 days & $0.106 \pm 0.086^{\mathrm{aA}}$ & $0.036 \pm 0.036^{\mathrm{aA}}$ & $0.178 \pm 0.044^{\mathrm{aA}}$ & $0.083 \pm 0.090^{\mathrm{aA}}$ & $0.078 \pm 0.082^{\mathrm{aA}}$ \\
\hline
\end{tabular}

Legend: ${ }^{\mathrm{a}-\mathrm{c}}-$ statistically significant differences $(\mathrm{p}<0.05)$ analysed in row

A-C - statistically significant differences $(\mathrm{p}<0.05)$ analysed in column

\section{CONCLUSION}

Goat's milk can be enriched with magnesium in the form of D-gluconate before pasteurization $\left(75^{\circ} \mathrm{C}\right)$ with maximum dose $20 \mathrm{mg}$ of magnesium for $100 \mathrm{~g}$ of milk. Higher doses of magnesium decreases $\mathrm{pH}$ and can lead to coagulation of proteins. Enrichment of goat's milk yoghurts with magnesium lowered the intensity of "goat" taste during cold storage. Moreover, enrichment with magnesium does not significantly affect on the cohesiveness and adhesiveness of yoghurts. Fortification with magnesium increases the hardness of yoghurts and this trend was continued throughout the whole period of cold storage.

\section{REFERENCES}

Bancerz B., Duś - Żuchowska M., Cichy W., Matusiewicz H. 2012. Wpływ magnezu na zdrowie człowieka. Przeglad Gastroenterologiczny, 7, 6, 359-366. DOI: http://dx.doi.org/10.5114/pg.2012.33043

Brendehaug J., Abrahamsen R.K., 1986. Chemical composition of milk from heard of Norwegian goat's. Journal of Dairy Research, 53, 211-221. DOI: http://dx.doi.org/10.1017/S002202990002481X

Ceballos L.S., Morales E.R., Gloria de la Torre Adarve, Diaz Castro J., Pérez Martinez L., Remedios Sanz Sampelayo M.2009. Journal of Food Composition and Analysis 22, 322-329. DOI: http://dx.doi.org/10.1016/j.jfca.2008.10.020

Courday C., Rembeau M., Feillet - Courday C., Gueux E., Tressol J.C., Mazur A., Rayssiguier Y.2005. Study of magnesium bioavailability from ten organic and inorganic $\mathrm{Mg}$ salts in $\mathrm{Mg}$ - depleted rats using a stable isotope approach. Magnesium Research 18(4), 215-223. PMID: 16548135 [PubMed - indexed for MEDLINE]

Danków - Kubisz R., 2007. Nowoczesne metody przetwarzania mleka koziego. Wiadomości Zootechniczne, R. XLV 1-2, 15-21.

Danków R., Pikul J., 2011. Przydatność technologiczna mleka koziego do przetwórstwa. Nauka. Przyroda. Technologie, 5 (2), 2-10. ISSN 1897-7820.

Hekmat S., Reid G., 2006. Sensory properties of probiotic yogurt is comparable to standard yogurt. Nutrition Research 26, $163-166 . \mathrm{DOI}$ : http://dx.doi.org/10.1016/J.NUTRES.2006.04.004

Jarosz M., Bułhak - Jachymczuk B., 2008. Normy żywienia człowieka. Podstawy prewencji otyłości i chorób niezakaźnych. Wydawnictwo Lekarskie PZWL, Warszawa. ISBN:9788320034219

Kocot J., 2014. Magnesium in Medicine and treatment. Journal of Elementology, s1179 - 1192. DOI: http://dx.doi.org/10.5601/jelem.2014.19.3.723

Kruk - Słomka M., 2012. Pożądane trio, czyli najważniejsze pierwiastki w organizmie ludzkim. Aptekarz Polski. 65/43. On line. ISNN 2353-13-71.

Lankes H., Ozer H.B., Robinson R.K., 1988. The effect of elevated milk solids and incubation temperature on the physical properties of natural yoghurt. Milchwiss., 53 (9), 510-513. ISBN 978-83-937001-2-7

Mituniewicz-Małek A., Dmytrów I., Balejko J.,Ziarno M. 2013. Komercyjne kultury probiotyczne lactobacillus sp. (lb. paracasei, lb. casei i lb. acidophilus) w napojach fermentowanych z mleka koziego. ŻYWNOŚĆ. Nauka. Technologia.

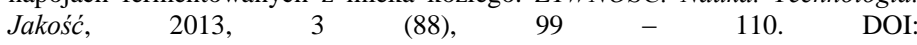
http://dx.doi.org/10.15193/zntj/2013/88/099-110

Pandya A. J., Ghodke K.M., 2007. Goat and sheep milk products other than cheeses and yoghurt, Small Ruminant Research, 68, 193-206. DOI: http://dx.doi.org/10.1016/j.smallrumres.2006.09.007

Park Y.W., Juàrez M, Ramos M., Haenlein G.F.W. 2007. Physico - chemical characteristic of goat and sheep milk. Science Direct, Small Rumintant Research 68, 88-113. DOI: 10.116/j.smallrumres.2006.09.013.

Pieczonka W., 2008. Niektóre uwarunkowania spożywania produktów z mleka koziego. Przegląd mleczarski, 1, 8-12. ISSN: 0478-6599.
Ścibisz I., Ziarno M., Mitek M., Zaręba D. 2012. Effect of probiotic cultures on the anthocyanins stability in blueberry yoghurts. LWT - Food Science and Technology, 49 (2), 208-212. DOI: http://dx.doi.org/10.1016/j.lwt.2012.06.025 Szczepanik A., Libudzisz Z., 2000. Mleko kozie i jego właściwości. Przegląd mleczarski, 5, 136-139.

Wszołek M., 1997. Przydatność technologiczna mleka koziego. Przegląd mleczarski, 1, 12-14. ISSN: 0478-6599

Zaręba D., Ziarno M., Obiedzinski M. 2012. Volatile Profile of Non-Fermented Milk and Milk Fermented by Bifidobacterium animalis subsp. lactis. International Journal of Food Properties, 15 (5), 1010-1021. DOI: http://dx.doi.org/10.1080/10942912.2010.513024 First posted on.

Ziarno M. 2004. Produkty mleczarskie wzbogacone w magnez. Przemysł spożywczy 58, 12, 38-41. Identyfikator YADDA: bwmeta1.element.baztecharticle-BPG4-0040-0005

Znamirowska A., Kalicka D., Pawlos M., Szajnar K., 2015 Quality of yoghurts from goat's milk enriched with magnesium chloride, The Journal of Microbiology, Biotechnology and Food Sciences, 4, 4, 369 - 372. DOI: http://dx.doi.org/10.15414/jmbfs.2015.4.4.369-372 